\title{
Evaluating the Competing Claims on the Role of Ownership Regime Models on International Drinking Water Coverage
}

\author{
Chadd Stutsman ${ }^{1}$, Kelly Tzoumis ${ }^{2} \&$ Susan Bennett $^{2}$ \\ ${ }^{1}$ International Studies, DePaul University, Chicago, IL 60614 USA \\ 2 Department of Public Policy Studies, DePaul University, Chicago, IL 60614 USA \\ Correspondence: Kelly Tzoumis, Department of Public Policy, DePaul University, Chicago, IL 60614 USA Tel: \\ 1-630-306-3351. E-mail: ktzoumis@depaul.edu
}

\author{
Received: May 10, 2016 Accepted: May 24, 2016 Online Published: May 31, 2016 \\ doi:10.5539/enrr.v6n2p145 URL: http://dx.doi.org/10.5539/enrr.v6n2p145
}

\begin{abstract}
While progress has been made for providing drinking water through the completion of the Millennium Development Goals and other international programs, millions of people still do not have access to clean drinking water. This study examines how drinking water coverage is impacted using three regime ownership models. Using the framework of the privately-owned, publicly-owned, and decentralized regime models, the impacts of water production, non-revenue water, and unit operation cost are evaluated for drinking water coverage. A sample of 144 utilities across 33 countries were sampled using data from the International Benchmarking Network for Water and Sanitation Utilities. Using ordinary least squares modeling, results indicate that predicting water coverage from water production, non-revenue water, and unit operational costs provided weak explanations of variation for both publicly-owned and decentralized regimes. None of the three regime models established a significant relationship between water coverage and all three independent variables. For publicly- and privately-owned water regimes, decreasing non-revenue water by plugging leaks and improving infrastructure can translate into higher rates of water coverage. For decentralized water regimes, higher levels of unit operational cost can increase water coverage. The regression analyses also showed that broad claims about regime ownership, efficiency, and improved water coverage should be suspect. None of the three regime models established a significant relationship between water coverage and all three independent variables. This suggests that the competing claims that privatized drinking water utilities as being more efficient or more able to provide water coverage as compared to other types of utilities in the literature is not supported when compared across countries.
\end{abstract}

Keywords: international drinking water, drinking water regimes, international water coverage

\section{Introduction}

\subsection{What Impact do Ownership Regime Models of on Drinking Water Coverage?}

In 2000, Cochabamba, Bolivia privatized its municipal water utility resulting in massive protests by the city's residents. Typically referred to as the 'Cochabamba Water Wars', this conflict epitomizes the long debate about the impact of ownership regime models on drinking water coverage via water utilities. How freshwater is framed as a natural resource, and managed, impacts coverage, which is vital to the human population. The World Health Organization (WHO) estimates that 842,000 people die each year from diarrhea as a result of unsafe drinking water. In addition, at least 1.8 billion people use drinking water contaminated with feces (World Health Organization, 2015). Since 1990, some progress in providing access to drinking water has been reported as part of the completion of the Millennium Development Goals in 2015. There are approximately 4.2 billion people getting drinking water through piped-connections, and another 2.4 billion people accessing water through improved sources including public taps, protected wells, and boreholes. However, in 2013, it was estimated that 783 million people still do not have access to clean drinking water (United Nations Educational, Scientific, and Cultural Organization, 2015). Academics, global leaders, and practitioners have debated for decades on the best ways to increase coverage for people across the globe.

The World Bank has taken what has been termed a 'neo-liberal' or market approach towards drinking water coverage as how it frames this critical natural resource. This argument is that privately-operated water utilities 
which position water as an economic good rather than a public good are superior to other models of delivery. When framing drinking water as a commodity, it can be managed under a market-based approach that will discourage overconsumption and waste while generating much needed revenue for the infrastructure improvements of water utilities (privately-owned water coverage). Likewise, improvements to infrastructure can increase coverage by lowering the cost of piped-water delivery which may not be accessible in a widespread manner. However, if drinking water coverage is framed using an opposite approach, where coverage is a universal human right, and it is not commoditized as a private good, then ownership of water utilities would remain in the public sphere (publicly-owned water coverage). The delivery of water then would be more accessible to people, but perhaps more costly to deliver. A third approach to framing freshwater as a natural resource is having organizations of local citizens with rights to access drinking water. Of course, this framing does not give individual citizens the rights to drinking water, but in this framework, water utilities could eliminate waste from both local knowledge of natural resource management and increased accountability (decentralized water coverage). These three framing approaches serve as the foundation for the three ownership regimes for water coverage evaluated in multivariate regression modeling in this research.

Using data from the International Benchmarking Network for Water and Sanitation Utilities (2015), this research focuses on comparing three ownership regime models of water coverage (publicly-owned, decentralized, and privately-owned) for piped-water delivery provided by water utilities. The regimes are examined for the amount of water coverage predicted from water production, amount of non-revenue water (waste or seepage), and unit operational costs. The evaluation of competing claims in the literature of these three ownership regimes is the foundation of the comparison.

\subsection{Literature Review}

\subsubsection{Publicly-Owned Regimes}

Historically, for the most part, utility ownership of drinking water was the purview of states and municipalities. During the $18^{\text {th }}$ and $19^{\text {th }}$ centuries, states and municipalities were the only organizations capable of expanding water service to rapidly growing populations. This largely contributed to the ascendancy of states and municipalities in water delivery. States and municipalities as water providers began with European countries and expanded globally through colonialism. France was a notable exception where private companies contracted by municipalities serve as utility operators.

Publicly-owned water utilities are owned and managed by a national or state/provincial government. Water is viewed as a universal good and a "natural resource monopoly" that needs ownership and management by a publicly-owned regime for the protection of water coverage. Public water utilities in various countries are responsible for the maintenance and operation of all levels of water distribution and sanitation (Baietti, Kingon, \& van Ginneken, 2006). Typically, a public water utility can be managed as a ministry or department, a statutory body, or as a public company, each with different management structures and oversight. Water utilities that are managed as a ministry or department of the government may operate under a system of direct control and oversight and do not exist as a separate legal entity. A water utility that is a statutory body is typically owned by the government and operates under public law, with a legal act establishing it as an autonomous corporate body. The publicly-owned regime is generally comprised of governments with a centralization of policymaking decisions. In this regime, water is framed as a public good that can, and should be, delivered by the state because of the critical role it has in sustaining life.

\subsubsection{Privately-Owned Regimes}

According to Baietti, et al. (2006), as part of a general move to market-led systems in the 1980s and 1990s, a new paradigm emerged to transform utilities into more modern service delivery organizations that emphasize operational and financial sustainability. It was thought that public-owned regimes for water coverage were costly, and not effective in maintaining affordable water delivery with maintenance of infrastructure. There was wide optimism that the private sector would resolve much of the performance problems of utilities and mobilize scarce financing to sustain growth and expand coverage. Central to this regime was a definition of water as a commodity to be privatized and managed in the market place. This "commodification" of water access took place which is the process of converting a good or service formally subject to many non-market social rules into one that is primarily subject to market rules (Gleick \& Reyes, 2002).

In the privately-owned regime, private companies are thought to be better equipped at water delivery than state or municipal management (Bakker, 2007, 2010). The issue has been supported for several reasons: first, public water agencies have been unable to satisfy the most basic needs for water for all humans; second, major multinational corporations have greatly expanded their efforts to take over responsibility for a larger portion of the 
water service market than ever before. Also, it is thought that commodification of water can have a positive effect on economic and social development by focusing on the implementation of public policies for the sustainable consumption of water, commercializing environmental awareness, and communicating consumers' responsibilities towards the use of water (Patsiaouras, Saren, \& Fitchett, 2014).

Proponents of privatization, occasionally referred to as 'market liberals' or 'neoliberals', are characterized by the belief "that the free market is the best mechanism to maximize resource consumption, efficiency, and allocation." In essence, these theories advocate for the removal of government ownership and the liberalization of the market. Market advocates argue that public resources, such as drinking water, will not be efficiently utilized unless managed by the private sector. Privatization treats water as an economic good by establishing a price and concurrently a market. According to the advocates of this regime, priced water will be treated as a commodity giving government, industry, and society incentive to conserve and protect it. In addition, a market will bring about investment and improvements in water infrastructure and technology. Through efficiency gains and better management, private companies will be able to lower prices, improve performance, and increase cost recovery, enabling systems to be upgraded and expanded (Bakker, 2007). Market advocates often argue that publicly-owned water utilities attempt to ensure affordability by using cost subsidization schemes to keep drinking water tariffs low. Segerfeldt (2005) argues that such subsidization schemes set prices so low "that on average it only covers about 30 percent of the water supplies expenses." In essence, public water utilities are portrayed as lacking the adequate cost recovery needed to prevent infrastructure deterioration and an increase in inaccessibility of piped drinking water. Essentially, privatization proponents commonly argue that privatized water utilities' profit motive ensures cost recovery, which is used for infrastructure maintenance and expansion. While private sector involvement has indeed increased in the last decade, it has substantially fallen short of expectations that it would help turn around this sector. In essence, private financing has only accounted for less than 5 percent of the total investment in water supply and sanitation over the last 20 years (Baietti, Kingon, \& van Ginneken, 2006). At the same time, some public utilities have become more autonomous and accountable. Some have improved their performance without involving the private sector and working totally within a public environment of key stakeholders and funding sources (Hall, Lobina, \& de la Motte, 2005).

The privately-owned regime has encountered challenges to its use of water as a commodity. Recently there has been a shift in the ownership regime in Europe and developing countries towards re-municipalization where there is a return of water coverage to total public ownership, some from new citizen pressures for less private regime dominance of water coverage (Zamzami \& Ardhianie, 2015). This trend contradicts neoliberal theorists, international financial institutions, and the expectations of superior private sector performance. Also, evidence increasingly points to re-municipalization as a credible promise of a better future for public water services and their beneficiary communities (Lobina, 2015). This shift has been also received criticism from recent austerity packages in Europe where water privatization is planned for increasing revenue for the state (Hall \& Lobina, 2012). Successful public utilities are still the exception, however, and since most people in developing countries are under the jurisdiction of public utilities, the result is that much of the world's population is still not adequately served (Baietti, Kingon, \& van Ginneken, 2006).

Privatization of water utilities exists on a spectrum. At one end of the spectrum a private company may have complete ownership of a water utility; while at the other end a private company may be contracted by the state to manage a utility. When a private company completely owns a water utility, they own the infrastructure for processing (plants and sanitation) with delivery (water pipes). Often they have more influence over business decisions allowing more capability to increase profits. At the opposite end of the spectrum a private company contracted to run a utility will have less influence over business decisions and will be more dependent on generating profits through efficiency gains. Despite the variability in ownership, perception of water is similar. Privatized water utilities view water as a commodity and seek to maximize profits through efficiency gains. Private utilities strive to produce more water at lower cost while decreasing non-revenue water (which is seepage or waste).

\subsubsection{Decentralized-Owned Regimes}

While there is a range of what constitutes publicly-, and privately-owned water regimes, there is a third type of regime separate from these other two that reflects more of a hybrid approach. Decentralized ownership regimes are operated by local entities such as city council, municipal government, drinking water association, or a water cooperative. Similar to publicly-owned water utilities, decentralized water utilities view water as a universal good. The difference is that utility governorship is handled at the local-level. Decentralization can occur in a variety of ways. The focus of this approach is that there are improvements in water coverage by increasing user influence to provide support for raising funding to support infrastructure. Moreover, in many countries, there has also been a 
move to decentralize decision-making down to the lowest practical level and place greater policy and oversight responsibilities on municipal governments. For example, local entities - city council, municipal government, drinking water association, or a water cooperative - can be given decision-making ability over water utilities and the authority to collect revenue in the forms of taxes or tariffs (Ribot, 2002). The local water entity may then serve as the policymaking and regulating body. Reporting to that body in the organization is a service operator that may be set up and charged with the day-to-day operations of the water utility. Alternatively, service operations may be contracted out to a private company. Under a mixed capital model, the municipality may choose to sell a small fraction of utility ownership to smaller water associations operating in the service areas. Dickson (2006) found that in Honduras decentralization was an effective method, particularly compared to the more centralized regimes of the privately and publicly owned delivery of water coverage (Dickson, 2006). Likewise, Renzetti \& Dupont (2003) reveal that there is no compelling evidence of private utilities outperforming public utilities or that privatizing water utilities leads to unambiguous improvements in performance

An increasingly popular form of decentralization is the water cooperative. Similar to publicly-owned regimes, cooperatives do not seek to create profit but to provide universal service coverage. They differ in that they are owned by the utility's consumers who are often called members. Cooperative governance structures are typically designed to allow membership voting rights, oversight, and accountability. A cooperative is an autonomous association of persons united voluntarily to meet their common economic, social, and cultural needs and aspirations through a jointly owned and democratically controlled enterprise. Utility management is accountable to member elected administrative and oversight boards, which are drawn from members. Performance of utility cooperatives varies widely. The practices and organization adopted are a determining factor in the results achieved. Well-functioning utility cooperatives provide dependable services to all members, do not discriminate, and are governed by a fair and uncorrupted management (Ruiz-Mier \& Ginneken, 2006). In general, private water utilities differ from public and decentralized water utilities in its framing of water. Both public and decentralized water utilities view water as a public good, inasmuch as it's both non-competitive and non-excludable. In contrast, private water utilities treat water as an economic good and seek profit maximization.

\subsection{Hypotheses Associated with the Ownership Regimes}

To compare the three regimes of drinking water ownership, the effects of three independent variables are important to evaluate: water production, nonrevenue water, and unit operational costs on water coverage. These variables are fundamental in the ability to provide water coverage. Since the privately-owned regimes were expected to be more efficient in delivery of water, it is expected that there will be increased water production, lower nonrevenue water and a lower unit of operational costs for increased water coverage. For publicly-owned regimes, the expectations are increased water production, higher nonrevenue water, and higher operational costs for increased water coverage. And, decentralized regimes should exhibit increased water production, lower nonrevenue water, and higher unit operational costs for increased water coverage. Table 1 outlines the hypotheses associated with each ownership regime for drinking water.

Table 1. Regime Hypotheses

\begin{tabular}{ll}
\hline Regime & Hypothesis \\
\hline Privately-Owned & \\
$\begin{array}{l}\text { Utilities that are owned, managed, or operated by the private } \\
\text { sector. }\end{array}$ & $\begin{array}{l}\text { Increased water production, lower nonrevenue } \\
\text { water, and lower unit operational costs should } \\
\text { result in increased water coverage. }\end{array}$ \\
$\begin{array}{l}\text { Publicly-Owned } \\
\begin{array}{l}\text { Utilities that are managed and operated by national or } \\
\text { provincial governments as a department/ministry, statutory } \\
\text { body, or a government company. }\end{array}\end{array} \begin{array}{l}\text { Increased water production, higher nonrevenue } \\
\text { water, and higher unit operational costs should } \\
\text { recentralization-Owned increased water coverage. }\end{array}$ \\
$\begin{array}{l}\text { Utilities that incorporate local entities like municipal } \\
\text { governments, city councils, or water boards or cooperatives. }\end{array}$ & $\begin{array}{l}\text { Increased water production, lower nonrevenue } \\
\text { water, and higher unit operational costs should } \\
\text { result in increased water coverage. }\end{array}$ \\
\hline
\end{tabular}




\section{Research Method and Design}

\subsection{Sample and Data Sources}

Sample utilities were identified through the World Bank's Private Participation in Infrastructure Advisory Facility (PPI, 2009) database. Samples were matched with the International Benchmarking Network for Water and Sanitation Utilities (IBNET) database, a non-governmental organization that is funded by United Kingdom's Department for International Development, The World Bank, and The United Nations Water and Sanitation Program. This organization is the world's largest performance database for water and sanitation utilities (International Benchmarking Network for Water and Sanitation Utilities, 2015). Utilities were selected based on having complete data for the three independent variables used in the model for hypothesis testing: water production, non-revenue water, and unit operational cost. This performance data is used to establish benchmarks for utility comparisons that assist practitioners, governments, and regulators in service improvement. Table 2 illustrates the criteria used for utility categorization into a regime type.

Table 1. Criteria for Utility Categorization

\begin{tabular}{ll}
\hline Regime Type & Criteria for Utility Categorization \\
\hline Private & $\begin{array}{l}\text { Utilities that are owned, managed, or operated by the private sector through a full divesture } \\
\text { sale, concession contract, lease agreement, or management contract. }\end{array}$ \\
Public & $\begin{array}{l}\text { Utilities that are managed and operated by national or provincial governments as a } \\
\text { department/ministry, statutory body, or a government company. }\end{array}$ \\
Decentralization & $\begin{array}{l}\text { Utilities that incorporate local entities like municipal governments, city councils, or water } \\
\text { boards in management process. }\end{array}$ \\
\hline
\end{tabular}

Using the IBNET database, 144 water utilities were identified with complete information from 33 countries which were identified by the World Bank as having "developing economies". The World Bank classifies national economies annually based on estimates of gross national income (GNI) per capita for the prior year. Economies identified as low- and middle-income economies are often referred to as developing economies. Countries with a GNI below $\$ 976$ were considered low-income and those with a GNI between $\$ 976$ and $\$ 3,855$ were considered middle income. This group included a wide variety of countries, including most of Latin America, several African countries, two Eastern European countries, and several Asian countries, including China and India. Though the sample represents a broad range in terms of size, geography, demographics, history, and politics, it is limited to countries having a similar level of economic development. This type of a sample is common in the pro-privatization literature and research. Implementation studies, of course, often emphasize the importance of context in policy considerations while the pro-privatization arguments are made from the neoliberal approach that generally argue in favor of market approaches in all circumstances. Countries such as those in the sample are often urged or even required to take a market approach by international funders such as the World Bank and the IMF. Testing the three models for water provision across a wide range of developing countries, then, seems an appropriate test of the pro-privatization model in comparison to the public, and decentralized models.

An attempt to take variations in the countries' context fully into account would require country specific analyses. Given the limited number of water utilities in each country (most had fewer than 10) and the presence of only one of the three types of water utilities in most of the countries, it would not be possible to conduct a statistical analysis to compare the three types using a country specific approach. Table 3 outlines the countries included in the sample, along with the number of utilities and regime types. The sample included 54 utilities from the privately-own regime type, 53 utilities from the publicly-own regime type, and 37 utilities from the decentralized regime type.

One critique of the sample is that it is too broad, and the scope should be limited to a specific region with similarities in geography, demographics, history, economics, and politics. It is not uncommon for studies supporting privately-owned regimes approach to drinking water coverage to use similar data sets to test claims of improved efficiency and/or water coverage. This analysis intends to engage in a similar exercise to test the significance of the regime influence on water coverage. This sample is also influenced by data availability, and most significantly, by the lack of data provided to the IBNET database. This would have some impact on external validity by not including more of countries with water coverage regimes. IBNET's data is collected by 
participating water utilities self-reporting measurement data on service coverage, water consumption and production, cost and staffing, and non-revenue water. Data is reported with the use of the IBNET tool-kit, which is a collection of spreadsheets requiring specific information. The fact that data is collected through a self-reporting process does bring legitimate questions of validity to the process.

Table 3. Sample Utilities by Country

\begin{tabular}{|c|c|c|c|c|}
\hline Country & \# Utilities & Private & Public & Decentralized \\
\hline Argentina & 6 & 4 & 1 & 1 \\
\hline Armenia & 2 & 2 & 0 & 0 \\
\hline Benin & 1 & 0 & 1 & 0 \\
\hline Bolivia & 2 & 0 & 0 & 2 \\
\hline Brazil & 23 & 0 & 23 & 0 \\
\hline Burkina Faso & 1 & 0 & 1 & 0 \\
\hline Chile & 11 & 10 & 0 & 1 \\
\hline China & 2 & 2 & 0 & 0 \\
\hline Columbia & 25 & 13 & 0 & 12 \\
\hline Costa Rica & 1 & 0 & 1 & 0 \\
\hline Ecuador & 1 & 1 & 0 & 0 \\
\hline Gabon & 1 & 0 & 1 & 0 \\
\hline India & 6 & 0 & 0 & 6 \\
\hline Kyrgyz Republic & 1 & 1 & 0 & 0 \\
\hline Lao PDR & 10 & 0 & 10 & 0 \\
\hline Malaysia & 1 & 1 & 0 & 0 \\
\hline Mali & 1 & 0 & 1 & 0 \\
\hline Mauritania & 1 & 0 & 1 & 0 \\
\hline Mexico & 2 & 2 & 0 & 0 \\
\hline Mozambique & 1 & 1 & 0 & 0 \\
\hline Niger & 1 & 0 & 1 & 0 \\
\hline Panama & 1 & 0 & 1 & 0 \\
\hline Paraguay & 4 & 0 & 4 & 0 \\
\hline Philippines & 3 & 3 & 0 & 0 \\
\hline Poland & 1 & 0 & 0 & 1 \\
\hline Romania & 1 & 1 & 0 & 0 \\
\hline Russia & 15 & 13 & 2 & 0 \\
\hline Rwanda & 1 & 0 & 1 & 0 \\
\hline South Africa & 14 & 0 & 0 & 14 \\
\hline Togo & 1 & 0 & 1 & 0 \\
\hline Tunisia & 1 & 0 & 1 & 0 \\
\hline Uganda & 1 & 0 & 1 & 0 \\
\hline Uruguay & 1 & 0 & 1 & 0 \\
\hline Total & 144 & 54 & 53 & 37 \\
\hline
\end{tabular}




\subsection{Design}

Using the utilities identified from IBNET, regression models were designed using an ordinary least squares (OLS) approach. The purpose was to determine the impact of water production, nonrevenue water, and unit cost to drinking water coverage. Regression analysis will measure the strength of the relationship between an ownership model's performance in water coverage. The first independent variable, water production, provides insight into the production side of drinking water coverage. Water production is measured by liters per person per day and expresses the total annual water produced and supplied by the utility to the distribution system. Tracking and measuring this indicator will show which management models produce higher level of water and if there is an identifiable relationship between water coverage and water production.

The second independent variable, non-revenue water, will test the amount of wasted water produced by sample utilities. Non-revenue calculates the difference in water produced and water sold in order to establish how much water is lost within the distribution network before it reaches the consumer. An analysis of water lost can provide insights into the health of a distribution system. Noted earlier, a criticism of publicly-owned regime water utilities is its failure to curb waste because it is treated as a common good, whereas privatization gives water an economic value that discourages waste. Regression analysis tests the relationship between an ownership model's performance in non-revenue water and water coverage to evaluate this issue of wasting water.

The final independent variable, unit operational cost, measured the health of a utilities infrastructure. Unit operational cost takes the total operational expenses of water utilities (including staffing, infrastructure, and maintenance) and divides them by the annual volume sold to show a bottom line assessment of the mix of resources used to achieve the outputs required. This variable shows how much it costs to provide water to consumers. Lower costs could indicate a better performing water delivery system coupled with cost effective management and staffing. Regression analysis tests an ownership model's performances in unit operational cost and water coverage.

Water coverage as the dependent variable is defined as the percentage of population with coverage to water services as a percentage of the total population under utility's nominal responsibility. There are several reasons for using water coverage as a dependent variable. First, it measures the percentage of the population within the specific utility's service district that has coverage to drinking water services, including both household connections and public access water points. This makes it the best indicator of water coverage to compare across the three regimes. Second, the dependent variable of water coverage provides insight in a nation state's conception of development and its implementation through infrastructure policies. The United Nations Development Report 3, "Water in a Changing World" emphasizes how a lack of sustainable water coverage could inhibit development. Finally, water coverage as a dependent variable, unlike the three independent variables, measures distribution and not production or delivery. The three independent variables are typically used for benchmarking effectiveness and efficiency. Table 4 provides the definition of the variables used in the regression model.

Table 4. Variables for the Ordinary Least Square Regression Model

\begin{tabular}{ll}
\hline Variables & Definition \\
\hline Water Coverage (y) & $\begin{array}{l}\text { Percentage of the total population under utility's nominal responsibility with } \\
\text { coverage to water services. }\end{array}$ \\
Water Production (x1) & $\begin{array}{l}\text { Liters/person/day; Total annual water sold expressed by population served per } \\
\text { day. }\end{array}$ \\
Non-Revenue Water (x2) & $\begin{array}{l}\text { Difference between water supplied and water sold expressed as a percentage } \\
\text { of net water supplied. Reflects waste and/or seepage. }\end{array}$ \\
Unit Operational Cost (x3) & Annual water service operational expenses/Total annual volume sold. \\
\hline
\end{tabular}

In sum, several predictions are made comparing the different water regime types. For instance, decentralized water systems are expected to have the most positive impacts on water allocation, infrastructure improvement and waste reduction. Non-revenue water, water production, and unit operational cost should be equal or better to privatization levels and water coverage should be equal or better to publicly managed utilities. For the privately-owned regime, utilities should perform well in non-revenue water, unit operational cost, and water production. Thus, this regime should have comparatively lower levels of non-revenue water and operational 
costs while maintaining higher levels of water production. Finally, the publicly-owned regime, compared to the other two regimes, should have less infrastructure investment and higher levels of waste, and a poorer performance in water allocation. Thus, a lower level of water coverage is expected for this regime coupled with higher levels of operational cost and non-revenue water, and lower levels of water production.

To ensure the three variables used in the model to predict water coverage were independent and not overlapping in definition with each other, a multicollinearity test was run to explore possible linkages between the three independent variables- water production, non-revenue water, and unit operational cost. A weak inverse correlation of multicollinearity was found between water production and non-revenue water (Pearson's $r=-.40$; $\mathrm{sig}=.00)$. A possible explanation of this is that water production involves water moving through a utility's infrastructure. Non-revenue water measures water leaking out of a utility's infrastructure. There was no multicollinearity detected between water production and unit operational cost (Pearson's $\mathrm{r}=-.15$; $\mathrm{sig}=.08$ ). Additionally, there was no multicollinearity detected between non-revenue water and unit operational cost (Pearson's $\mathrm{r}=-.11$; sig $=.19$ ). These results demonstrated the independence of these three variables with only minor multicollinearity between water production and non-revenue water which is not expected to have any impact on the regression models (Table 5).

Table 5. Regression Model Results for Privately-Owned Regime

\begin{tabular}{llll}
\hline $\mathrm{N}=144$ & Water Production & Non-revenue Water & Unit Operational Cost \\
\hline Water Production & 1 & $.40^{* *}$ & -0.15 \\
Non-Revenue Water & $0.40^{* *}$ & 1 & .11 \\
Unit Operational Cost & -0.15 & .11 & 1 \\
\hline
\end{tabular}

Note $^{*} \mathrm{p}<0.05$.

\section{Results}

OLS regression models were used to identify statistical relationships between the water coverage of water utilities (categorized as publicly-owned, privately-owned, or decentralized) and three independent variables that measure a utility's efficiency. To test the assumption that regime models impact water coverage through efficiency, regression analysis would need to establish a relationship between at least one ownership model's (private, public, or decentralized) water coverage and all three independent variables (water production, non-revenue water, and unit operational cost). The prediction included that all three regime models should show relationships between water coverage and the three independent variables.

\subsection{Privately-Owned Water Utilities Regime and Impact to Water Coverage}

Multiple regression analysis of privately-own regimes for water utilities was used to investigate effects of water production, non-revenue water, and unit operational cost on water coverage showed a weak and significant relationship (adjusted $\mathrm{R}^{2}=.308, \mathrm{~F}=8.857, \mathrm{p}<.05$ ). The hypothesis that there would be a significant relationship between increased water coverage from increased water production, decreased non-revenue water, and decreased unit operational cost for the privately-owned regime was partially upheld. Further analysis showed an inverse relationship between water coverage and non-revenue water (standardized $\beta=-.684, p=.00$ ) as predicted. There was no significant relationship for water production (standardized $\beta=.267, p=.06$ ) and unit operational cost (standardized $\beta=-.083, \mathrm{p}=.47$ ) with water coverage. Thus, for the privately-owned regime, the predictor of increased water coverage was decrease of non-revenue water with the other variables not being significant (Table 6).

Table 6. Regression Model Results for Privately-Owned Regime

\begin{tabular}{lll}
\hline & Standardized Beta & Sig. \\
\hline Water Production & .267 & .06 \\
Non-Revenue Water & -.684 & .00 \\
Unit operational cost & -.083 & .47 \\
$(\mathrm{~N}=54)$ & & \\
\hline
\end{tabular}

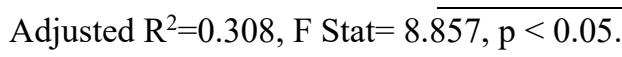




\subsection{Publicly-Owned Utilities Regime and Impact to Water Coverage}

Multiple regression analysis of public water utilities investigated effect of water production, non-revenue water, and unit operational cost on water coverage showed a weak and significant (adjusted $\mathrm{R}^{2}=.113, \mathrm{~F}=3.201, \mathrm{p}<.05$ ). The hypothesis for the publicly-owned regime was that there would be a significant relationship between increased water coverage from water increased production, increased non-revenue water, and increased unit operational cost. This hypothesis was not upheld and yielded results that were not predicted. Analysis showed an inverse relationship between water coverage and non-revenue water (standardized $\beta=-.481, p=.01$ ). Meaning that as non-revenue water increased, water coverage decreased. There was no significant effect on water production (standardized $\beta=.113, \mathrm{p}=.46$ ) or unit operational cost (standardized $\beta=-.249, \mathrm{p}=.10$ ) on water coverage. Thus, for the publicly-owned regime, the hypothesis was not upheld for the variables of water production and unit operation cost, and the relationship predicted for non-revenue water was in the inverse direction than predicted. The results indicate that for publicly-owned regimes, decreased non-revenue water leads to increased water coverage (Table 7).

Table 7. Regression Model Results for Publicly-Owned Regime

\begin{tabular}{lll}
\hline & Standardized Beta $(\mathrm{N}=53)$ & Sig. \\
\hline Water Production & .113 & .46 \\
Non-Revenue Water & -.481 & .01 \\
Unit operational cost & .249 & .10 \\
$(\mathrm{~N}=53)$ & & \\
\hline
\end{tabular}

Adjusted $\mathrm{R}^{2}=.113$, F Stat $=3.201, \mathrm{p}<0.05$.

\subsection{Decentralized Regime: Decentralized Water Utility and Impact to Water Coverage}

Multiple regression analysis of decentralized water utilities was used to investigate the effect of water production, non-revenue water, and unit operational cost on water coverage (adjusted $\mathrm{R}^{2}=.094, \mathrm{~F}=2.245, \mathrm{p}<.05$ ). The model showed overall very weak results. For this regime, it was hypothesized that there would be a significant relationship between increased water coverage and decreased water production, decreased non-revenue water, and decreased unit operational cost which was not upheld. In fact, the analysis showed significant effect of increased unit operational cost (standardized $\beta=.383, p=.03$ ) in increased water coverage which was not predicted. There was no significant effect of water production (standardized $\beta=.288, \mathrm{p}=.09$ ) and non-revenue water (standardized $\beta=.086, p=.60$ ) on water coverage. For the decentralized water regime, this was the weakest model, and the relationship between increased non-revenue water and increased water coverage was not expected (Table 7).

Table 7. Regression Model Results for Decentralized Regime

\begin{tabular}{|c|c|c|c|}
\hline & $\begin{array}{l}\text { Standardized } \\
(\mathrm{N}=37)\end{array}$ & Beta & Sig. \\
\hline Water Production & .288 & & .09 \\
\hline Non-revenue Water & .086 & & .60 \\
\hline Unit operational cost & .383 & & .03 \\
\hline
\end{tabular}

Adjusted $\mathrm{R}^{2}=.094, \mathrm{~F}$ Stat $=2.245, \mathrm{p}<0.05$.

\section{Discussion}

The implications for this research can help guide the discussion on which regime type is best suited for providing water coverage in the most efficient manner. While there are support for all three regimes in the literature, the results show that one particular regime type did not demonstrate superiority over the others. However, some findings did give some important information when considering different regime types. For publicly- and privately-owned water regimes, decreasing non-revenue water by plugging leaks and improving infrastructure can translate into higher rates of water coverage. For decentralized water regimes, higher levels of unit 
operational cost can increase water coverage. The regression analyses also showed that broad claims about regime ownership, efficiency, and improved water coverage should be suspect. Not one regime model established a significant relationship between water coverage and all three independent variables. Also, the models were not able to explain much of the variation of water coverage for the publicly-owned or decentralized regimes. According to Budds (2003), water coverage is not some inherent contradiction between private profits and the public good, because neither publicly- nor privately-owned utilities are well suited to serving the majority of low-income households with inadequate water and sanitation, and because many of the barriers to service provision in poor settlements can persist whether water and sanitation utilities are publicly- or privately-operated. This is not to say that well-governed localities should not choose to involve private companies in water and sanitation provision, but it does imply that there is no justification for international agencies and agreements to actively promote greater private sector participation on the grounds that it can significantly reduce deficiencies in water and sanitation services in the South. Future research into water coverage modeling in terms of variables that would include sociopolitical aspects of countries where the regimes are located which may yield stronger results in the decentralized and publicly-owned regimes.

\section{Acknowledgements}

A special note of acknowledgement to Dr. Kaveh Ehsani, DePaul University for working with the authors on the development of the manuscript.

\section{References}

Baietti, A., Kingon, W., \& van Ginneken, M. (2006). Characteristics of Well-Performing Public Water Utilities. World Bank Group. Water Supply and Sanitation Sector Board of the Infrastructure Network Note no. 9.

Bakker, K. (2007). The 'Commons' Versus the "Commodity': Alter-Globalization, Anti-Privatization and the Human Right to Water in the Global South. Antipode, 39(3), 430-455. http://dx.doi.org/10.1111/j.1467 $-8330.2007 .00534 . x$

Bakker, K. (2010). Privatizing Water: Governance Failure and the World's Urban Water Crisis. Ithaca: Cornell University Press.

Budds, J. (2003). Are the Debates on Water Privatization Missing the Point? Experiences from Africa, Asia and Latin America. Environment \& Urbanization, 15(2), 87-114. http://dx.doi.org/10.1177/095624780301500222

Dickson, E. (2006). Management Models of Water and Sanitation: Approaches to Decentralization in Honduras. Canada: International Development Research Centre.

Gleick, P. W., \& Reyes, R. (2002). The New Economy of Water: The Risks and Benefits of Globalization and Privatization of Fresh Water. Oakland: Pacific Institute.

Hall, D., \& Lobina, E. (2012). Water Companies and Trends in Europe 2012. Greenwich, UK: Public Services International Research Unit.

Hall, D., Lobina, E., \& de la Motte, R. (2005). Public Resistance to Privatization in Water and Energy. Development in Practice, 15(3 and 4), 286-281. http://dx.doi.org/10.1080/09614520500076126

Herrera, V., \& Post, A. (2014). Can Developing Countries both Decentralize and Depoliticize Urban Water Services? Evaluating hte Legacy of the 1990s Reform Wave. World Development, 64, 621-641. http://dx.doi.org/10.1016/j.worlddev.2014.06.026

International Benchmarking Network for Water and Sanitation Utilities. (2015). IBNET Database. Retrieved from https://www.ib-net.org/

Lobina, E. (2015). In S. Kishimoto, E. Lobina, \& O. Petitjean (Eds.), Our Public Water Future: The Global Experience with Remunicipalization (pp. 6-18). Paris: Transnational Institute.

Patsiaouras, G., Saren, M., \& Fitchett, J. (2014). The Marketplace of Life? An Exploratory Study of the Commercialization of Water Resources through the Lens of Macromarketing. Journal of Macromarketing, 35(1), 23-35. http://dx.doi.org/10.1177/0276146714538454

Pierce, G. (2014). Beyond the Strategic Retreat? Explaining Urban Water Privatization's sallow Expansion in Low- and Middle-income Countries. Journal of Planning Literature, 30(2), 119-131. http://dx.doi.org/10. $1177 / 0276146714538454$

Renzett, S., \& Dupont, D. (2003). Ownership and Performance of Water Utilities. Greener Management International, 42(1), 9-19. http://dx.doi.org/10.9774/GLEAF.3062.2003.su.00004 
Ribot, J. (2002). Democratic Decentralization of Natural Resources: Institutionalizing Popular Participation. World Resources Institute.

Ruiz-Mier, F., \& Ginneken, v. M. (2006). Consumer Cooperative: An Alternative Institutional Model for Delivery of Urban Water Supply and Sanitation Services? Washington, DC: World Bank Water Supply and Sanitation Sector Board.

Schiffler, M. (2015). Water, Politics and Money" A Reality Check on Privatization. Switzerland: Springer International Publishing. http://dx.doi.org/10.1007/978-3-319-16691-9

Segerfeldt, F. (2005). Water for Sake: How Business and the Market Can Resolve the World's Water Crisis. Washington, DC: Cato Institute.

The World Bank. (2009). Public Private Infrastructure Advisory Facility. "PPI Glossary - Private Infrastructure Projects - The World Bank \& PPIAF.” http://ppi.worldbank.org/resources/ppi_glossary.aspx

United Nations Educational, Scientific, and Cultural Organization. (2009) World Water Development Report 3. Retrieved from http://webworld.unesco.org/water/wwap/wwdr/wwdr3/pdf/WWDR3_Water_in_a_Changing _World.pdf

United Nations Educational, Scientific, and Cultural Organization. (2015). United Nations World Water Day 2013. International Year of Water Cooperation Facts and Figures. Retrieved from http://www.unwater.org/ water-cooperation-2013/water-cooperation/facts-and-figures/en/

World Health Organization. (2015). Drinking Water Fact sheet no. 391. Media Centre. Retrieved from http://www.who.int/mediacentre/factsheets/fs391/en/

Zamzami, I., \& Ardhianie, N. (2015). An end to the Struggle? Jakarta Residents Reclaim their Water System. In S. Kishimoto, E. Lobina, \& O. Petitjean (Eds.), Our Public Water Future: The Global Experience with Remunicipalization (pp. 40-49). Paris: Transnational Institute.

\section{Copyrights}

Copyright for this article is retained by the author(s) with first publication rights granted to the journal.

This is an open-access article distributed under the terms and conditions of the Creative Commons Attribution license (http://creativecommons.org/licenses/by/3.0/). 